DOI: 10.31392/NPU-nc.series14.2019.27.18

УДК 378:793.3

Чжан Юй

\title{
Основи методики освосння національних мистецьких традицій майбутніми вчителями музики та хореографії
}

\begin{abstract}
У статті розглядається актуальна проблема збереження і розвитку національних мистецьких традицій, успішність рішення якої залежить від ефективності масової мистецької освіти, зокрема від ступеню готовності вчителів до виконання даної соціокультурної місії. Основний зміст роботи присвячено обговоренню педагогічних підходів і принципів, які покладено в основу розробленої в руслі дослідження методики підготовки майбутніх учителів музики і хореографії в педагогічних вишах. Визначаються головні педагогічні підходи - полікультурний, художньо-інтегративний (поліхудожній), герменевтичний i діяльнісний. Обговорюються провідні принципи педагогічного впливу (діалогу культур, семіотичного осмислення творів, контекстового аналізу семантики художніх знаків, розвивального навчання та ін.) і найбільш важливі методи навчання (культурологічного і компаративного аналізу, жанрового моделювання, інтерактивного навчання, педагогіки співпраці тощо).
\end{abstract}

Ключові слова: методика вищої освіти; музична освіта; національна мистецька традиція; педагогічний підхід; хореографічна освіта.

Актуальність дослідження. Традиція - фундаментальна категорія багатьох сучасних гуманітарних дисциплін, таких як соціологія, культурологія, історія, етнографія, філологія, мистецтвознавство. Термін традииія походить від стародавнього латинського слова traditio, яке буквально тлумачиться як «передача». Йдеться, перш за все, про передачу в історичному часі, від покоління до покоління, певного колективного досвіду. Також традицією називають $і$ самий цей досвід, без якого неможливо уявити існування і розвиток культури будь-якого суспільства та людства у цілому. Отже, поняття традиції звичайно визначається як «... анонімна, стихійно сформована система зразків, норм, правил тощо, якою керується у своїй поведінці досить широка і стійка група людей» [10, с. 741]. Філософи підкреслюють інваріантний характер традиції: «За суттю своєю традиція - це збереження того, що $є$, збереження, що здійснюється при будь-яких історичних змінах» [4, с. 334-335].

Традиція, на думку більшості митців та вчених, є основою художньої творчості. «Термін «традиція» широко використовується в характеристиці та оцінці естетичної та культурної значущості мистецтва цілих епох, напрямків і окремих художників, які зробили особливий внесок у скарбницю світової культури, які створили унікальні зразки - пам'ятники мистецтва. Якщо вірно, що без минулого немає майбутнього, то справжнє новаторство можливе лише на основі збереження традицій, їх творчого продовження і розвитку. Це справедливо як для мистецтва, так і для історичної творчості взагалі» [7].

Важко переоцінити роль і значення мистецьких традицій в існуванні національної культури, у становленні національної самосвідомості народу, особистісної національної ідентифікації людини. Ця функція традиційного мистецтва 3 кожним днем стає все більш актуальною у зв'язку з процесом культурної глобалізації, який невідворотно руйнує традиції національного мистецтва народів планети. Даний процес здійснюється, поперед усе, через експансію продуктів масово-популярного мистецтва. На відміну від творів народного і класичного мистецтва, такі продукти відрізняються бідністю художньої семантики, відсутністю зв'язку з етичними та естетичними цінностями людства.

Отже, об'єктивна культурна значущість національних мистецьких традицій в наші часи постійно зростає. Однак, їх стан від цього сам по собі не покращується. Традиція потребує уваги до себе, плекання, охорони, зберігання. Як влучно зауважив Х.-Г. Гадамер: «Навіть сама справжня і міцна традиція формується не просто природним шляхом, завдяки здатності до самозбереження того, що є в наявності, але вимагає злагоди, прийняття, турботи» [4, с. 309]. 
Школа (у найширшому сенсі цього слова) - це з давніх часів найбільш масштабний і потужний «механізм» зберігання i передачі колективного культурного досвіду, як загальнолюдського, так і національного. Це у повній мірі стосується мистецької освіти. Осмислене сприйняття новими поколіннями найкращих зразків світової художньої культури, практичне і наукове оволодіння мовами музики, хореографії та інших видів художньої творчості - це найбільш доступний, масовий і ефективний засіб освоєння національних мистецьких традицій. 3 цього слідує, що вчителі мистецтва мають приділяти першочергову увагу процесу усвідомлення і практичного освоєння в загальноосвітніх школах та інших освітніх установах національним мистецьким традиціям. Це навчально-виховне завдання має бути головною місією і святим обов'язком учителя мистецтва.

Надзвичайна значущість для системи освіти даного завдання була усвідомлена ще у стародавньому світі багатьма філософами, педагогами, діячами культури і мистецтва. Зокрема, особлива важливість народних звичаїв, фольклору, традиційного мистецтва завжди підкреслювалася в культурі Китаю. Одним з перших, хто заклав фундамент ціннісного ставлення до національної традиції був Кун-цзи (Конфуцій). Власну історичну місію вчений бачив у збереженні і передачі нащадкам стародавньої культури («вень»- 文). Він редагував $\mathrm{i}$ коментував старовинні зразки китайської народної традиції (до найбільш знаменитих зразків належить монументальна збірка пісенних текстів «Ши цзин»). У своєму вченні Конфуцій створив ідеальний образ людини, яка слідує традиції, дотримується етикету, виявляє благопристойність («лі» - 礼) і гуманність («жень» - 仁) [6, с. 76]. Шанобливе ставлення до традиції, зокрема до традиційного національного мистецтва, успадкували майже всі мислителі Китаю - від класиків середньовіччя (Дай Чжень, Ван Янмин, Тань Ситун, Чжан Цзай та ін.), аж до нашого часу (Лян Шумін, Сунь Ятсен, Фэн Юлань та ін.).

Західна думка також трактує традицію як одну 3 найбільш важливих категорій культурології, історії, суспільствознавства, етики та естетики (Аристотель, М. Богданов, Й. Гейзінга, Л. Гумільов, К. Леві-Строс, Платон, П. Сорокін, А. Швейцер та ін.). Значення традиційного мистецтва i, перш за все, фольклору для розвитку культури народу i формування його національної свідомості підкреслювали видатні діячі української національної культури: письменники, публіцисти, митці, педагоги. Так, наприклад, значення традицій музичного i хореографічного мистецтва для розвитку української культури зазначали В. Антонович, В. Вернадський, Б. Грінченко, М. Грушевський, М. Драгоманов, М. Костомаров, М. Лисенко, С. Миропольський, П. Сокальський, В. Сухомлинський, Л. Українка, К. Ушинський, І. Франко, П. Юркевич та ін.

Можна вважати, що особлива важливість традиційного національного мистецтва для справи «культуровідповідної освіти» (за терміном А. Дистервега) молодих поколінь $\epsilon$ загально визнаним положенням. Його практичним втіленням став педагогічний досвід багатьох педагогів музичного і хореографічного мистецтва, які у своїй роботі опиралися на національні художні традиції (Б. Барток, Е. Бальчитіс, Е. Башич, К. Василенко, В. Верховинець, В. Джуляну, В. Ковалив, З. Кодай, М. Лисенко, Ф. Лисек, К. Орф, Б. Тричков иа ін.). Втім, поняття національної мистецької традиції ще мало досліджено в теоретичному плані, зокрема як категорія педагогіки музичного і хореографічного мистецтва. Український дослідник хореографічного мистецтва Д. Шаріков наголошує на необхідності розвитку самостійної дисципліни - «етнохореології», яка має досліджувати генезис традиційних танців народів світу, соціокультурні обставини їх художньої екзистенції, зв'язок із обрядами та звичаями, їх жанри та стилі, особливості форми та художньо-образного змісту.

Дослідники практики мистецької освіти, в тому числі практики підготовки вчителів музики і хореографії в педагогічних вишах (Л. Андрощук, А. Максименко, Г. Ніколаї, Т. Разуменко, О. Таранцева, О. Чепалов та ін.) підкреслюють естетичну та етичну привабливість традиційного мистецтва, його ідейно-виховну важливість, впливовість на світогляд $\mathrm{i}$ національну самосвідомість учнів і студентів Водночас вони наголошують на необхідності оснащення навчального процесу новими сучасними методами викладання національних 
художніх традицій, науково обгрунтованими підходами до освоєння традиційного мистецтва в освітніх установах. Це масштабне завдання є поки що далеким від розв'язання. Педагоги дослідники рідко зосереджують увагу на конкретних проблемах методики, скажімо, на питаннях відбору дидактичного матеріалу, підходів до виявлення і герменевтичного розкриття семантики традиційного мистецтва, до формування умінь та інтринсивної мотивації (за Г. Гекгаузеном) щодо творчих дій в руслі традиційної художньої поетики тощо.

Таким чином, актуальність проблеми дослідження зумовлена, перш за все, протиріччям між об'єктивною потребою суспільства в збереженні і розвитку національних художніх традицій - з одного боку, і малою ефективністю відповідних методів впливу на художню свідомість учнівської молоді - $з$ іншого боку.

Метою цієё статті є визначення педагогічних підходів, принципів і методичних стратагем освоєння національних мистецьких традицій майбутніми вчителями музики i хореографії.

Виклад основного матеріалу. Приступаючи до визначення педагогічних підходів, які утворюють базис запропонованої методики, к першу чергу зазначимо полікультурний підxід. Він може бути пояснений за допомогою визначення, яке надано в українській «Енциклопедії освіти» щодо методики загальної шкільної освіти: «Полікультурне виховання - це процес цілеспрямованої соціалізації учнів, що передбачає оволодіння особистістю системою національних i загальнокультурних цінностей, комунікативних і емпатичних вмінь, що дозволяють школяреві здійснювати міжкультурну взаємодію і виявляти розуміння інших культур, а також толерантність стосовно іншокультурних носіїв» [5, с. 873].

Наведена характеристика цілком відповідає завданням підготовки майбутніх учителів музики і хореографії. Звичайно, що студенти, які обрали своєю майбутньою професійною діяльністю педагогічну діяльність у сфері мистецької освіти, які вже мають чималий досвід сприйняття, осмислення та практичного застосування художніх творів різних народів, проблема толерантності до нерідних культур та «іншокультурних носіїв» навряд чи $\epsilon$ гострою. Разом із тим, «розуміння інших культур», «оволодіння системою національних і загальнокультурних цінностей» - це якості, що обов'язково мають бути сформовані у педагогів мистецтва.

Цей вектор освіти добре усвідомлюється українськими фахівцями. За словами О. Щолокової, українські вчені «...наголошують, що школа XXI століття повинна стати центром полікультурного виховання, духовного самовизначення й самореалізації особистості». При тому, як зазначає дослідниця, специфіка полікультурного виховання і навчання «...полягає в органічній єдності регіонального і світового компонентів 3 пріоритетом на національну спрямованість, цілісність та безперервність, комплексність і варіативність впровадження мистецтва у навчально-виховний процес» [14, с. 38].

Даний підхід є вельми актуальним для педагогіки сучасного Китаю, де стрімко зростає масовий інтерес до художньої культури народів світу, що, в свою чергу, примушує китайських вчених по-новому оцінити традиційну національну культури своєї вітчизни (пошлемося на статтю Цзинь Сінь Сіня [12] та грунтовне дослідження Цзинь Лі «Культурні основи навчання. Схід і Захід» [11]. Сучасні китайські педагоги все більш ясно усвідомлюють важливу для художньо-естетичного виховання діалектику «свого і чужого».

Отже, головним педагогічним принципом, що конкретизує полікультурний підхід до освоєння національних мистецьких традицій є принцип діалогу між рідною, добре знайомою культурою та культурами інших народів світу. За думкою М.Бахтіна, який створив універсальну концепцію культурного діалогу: «У кожній культурі закладені величезні смислові можливості, які залишилися нерозкритими, що не усвідомленими i не використаними протягом усього історичного життя даної культури... Чужа культура тільки в очах іншої культури розкриває себе повніше і глибше... Один сенс розкриває свої глибини, зустрівшись і зіткнувшись з іншим змістом; між ними починається як би діалог, котра переборює замкнутість і однобічність цих смислів, цих культур... При такій діалогічній 
зустрічі двох культур вони не зливаються і не змішуються, кожна зберігає свою єдність і відкриту цілісність, але вони взаємно збагачуються» [1, с. 351-354].

Зокрема, для китайської мистецької освіти важливим $є$ «...поглиблення діалогу між західним і східним типами культур; прищеплення шанобливого ставлення до культурних звичаїв і традицій усіх народів, активний обмін їх надбаннями» [14, с. 40]

Логічним наслідком прийняття полікультурного підходу є застосування методів та понять культурологічного аналізу художніх явищ. Це означає, що будь-який артефакт, чи жанр, чи стиль національного традиційного мистецтва має розглядатися як феномен певної національної культури, в контексті головних iї сторін, інституцій, історичного стану, тенденцій розвитку. Наприклад, кожний твір традиційного хореографічного мистецтва має бути в ідеалі осмисленим в широкому контексті історичної епохи в житті нації, характеру матеріально-технічної культури суспільства, особливих властивостей світогляду, міфології, обрядів, звичаїв, усної та писемної літератури, художньо-творчої практики.

Зазначимо ще один важливий метод, дотичний до полікультурного підходу. Йдеться про метод порівняльно-історичного (або компаративного) аналізу культур та їх окремих галузей (релігій, звичаїв, літератури тощо), який сформувався у працях А. Веселовського, В. Вундта, В. Гумбольдта, Дж. Мердока, Л. Моргана, А. Перетца, Е. Тейлора, А. Тойнбі, Д. Фрезера та ін. Звичайно цей метод дослідження «...дозволяє шляхом порівняння виявляти загальне $\mathrm{i}$ особливе в розвитку країн і народів світу і причини цих подібностей і відмінностей» [3, c. 223]. Компаративний метод дослідження i викладання феноменів національного традиційного мистецтва (в парадигмі розвивального навчання ці види діяльності часто співпадають) є однаково ефективним, як стосовно розгляду одиничних художніх творів, так i при порівнянні жанрів, стилів, елементів поетики (сюжетів, архітектонічних типів, лексики, граматичних норм, технік творчості тощо).

Наступний педагогічний підхід визначено як художньо-інтегративний. В літературі (праці О. Бузової, Л. Масол, Г. Шевченко, Б. Юсова) його характеризують також як поліхудожній: «Поліхудожнє виховання передбачає залучення студентів до різних видів мистецтва, на відміну від монохудожнього, яке грунтується на одному з видів мистецтва» [2, c.5]. Для нашої методики більш продуктивним $\epsilon$, на наш погляд, не стільки звернення до всього видового різноманіття національних мистецьких традицій, скільки усвідомлення i практичне використання студентами можливостей інтеграції різних засобів художньої виразності в шедеврах традиційного мистецтва. Запропонована методика спрямована, таким чином, на створення живого знання про системну єдність мистецької традиції, що відбиває цілісність національної свідомості, національного художнього образу світу.

У психолого-педагогічному аспекті даний підхід проявляє себе, по-перше, у спрямуванні освітнього процесу на формування емпіричних уявлень і теоретичних знань про цілісність традиційного мистецтва, що проявляється у системних відносинах між видами і жанрами художньої творчості. Наявність у кожній національній жанрово-видовій системі індивідуально неповторних та спільних 3 іншими культурами властивостей обумовлює природність звернення у педагогічному процесі до методу жжанрового моделювання художньої культури.

Витоки даного методу в європейській науці знаходяться в «Поетиці» Аристотеля, а його розвитку сприяли філософські праці Г. Гегеля, Д. Дьюї, Б. Кроче, А. Габричевського, М. Кагана. У музикознавстві та хореології елементи жанрового моделювання культури використовували Г. Адлер, Т. Арбо, Б. Асаф’єв, І. де Грохео, Ж. Новерр, Й. Тінкторіс та ін. Педагогічну розробку даний метод знайшов у концепції Д. Кабалевського. Суть даного методу полягає у можливості репрезентації невичерпно багатого змісту художньої культури засобом понятійного моделювання ії видового і жанрового (як варіант - жанрово-стильового) складу, яка виявляє системну організацію мистецької практики, ступінь їі складності, головні елементи та системні зв'язки. Метод жанрового моделювання $є$ також тою ланкою, що поєднує полікультурний та художньо-інтерактивні підходи. За допомогою даного методу 
уможливлюється вивчення «...культур різних етносів, епох, соціальних класів і груп. Крім того, звернення до цілісного образу культури дозволяє простежити принципові зміни, що відбуваються «в рамках» однієї культури в ході ऑї розвитку» [13, с. 4]

По-друге, художньо-інтегративний підхід втілюється в комплексі методів формування практичних навичок та умінь майбутніх учителів музики і хореографії. Йдеться, головним чином, про: а) навички та психологічні установки синестетичного сприйняття художніх творів; б) уміння контролювати всі сторони процесу художньої виразності під час репродуктивних або імпровізаційно-творчих дій; в) уміння уявляти і «матеріалізувати» в конкретному художньому матеріалі оригінальний композиційний задум поєднання різних за видом традиційних засобів художньої виразності, тобто створювати синтетичний твір мистецтва в руслі певної національної мистецької традиції.

Зазначене положення $\epsilon$ особливо актуальним у підготовці майбутнього вчителя хореографії, який завжди має справу із художнім синтезом: танець зазвичай не вміщується в межі «монохудожнього» акту чи артефакту, він $є$ продуктом синтезу рухів і поз тіла із засобами музики, акторського мистецтва і прикладного образотворчого мистецтва (костюм, прикраси, аксесуари). При більш широкому куті бачення танець має генетичний зв'язок із міфами, ритуалами, звичаями, побутом, етикетом конкретної суспільної групи. Завдяки цьому він опосередковано пов'язаний з усією системою видів мистецтва в даному культурному середовищі.

Третя основа методики освоєння національних мистецьких традицій визначається як герменевтичний nidxid. Даний підхід є необхідним і цілком органічним для запропонованої методики. Його необхідність обумовлена тим, що кожна мистецька традиція має свою історію. Вік деяких традицій (наприклад, китайської) сягає декількох тисячоріч. Звичайно, що для кожного нового покоління студентів, освоєння старовинних зразків традиційного мистецтва є доволі непростим завданням. В умовах сучасної швидкості культурного розвитку народів світу навіть чверть сторіччя $є$ досить значною «дистанцією» між реаліями сьогодення i артефактами традиційного мистецтва минулого. Художній сенс останніх може здаватися молодим людям якимсь дивним, кумедним, малозрозумілими. Така педагогічна ситуація породжує необхідність пояснення учням смислу творів мистецтва. Не меншу проблему становить процес освоєння не своїх рідних національних традицій. I тут етнологічна «дистанція» між культурами може бути величезною, нездоланною для молодих людей. Наприклад, для китайських студентів дуже далекими і незрозумілими є мистецькі традиції народів Прибалтики, Скандинавії, Центральної Африки, Латинської Америки, Ближнього Сходу, Сибіру тощо. Більш знайомим для них є художні культури Кореї, Японії, Індії, Індокитаю, Індонезії. Втім, розуміння мистецтва навіть найближчих сусідів $\epsilon$ поверховим, мало корисним для мислення і діяльності.

Рішення даної проблеми потребує звернення до засобів педагогічної герменевтики (праці А. Линенко, А. Закірової, О. Олексюк, Г. Падалка, О. Полатайко та ін.). Специфіка даного підходу в контексті завдань освоєння національних мистецьких традицій полягає в тому, що педагогічна інтерпретація художніх творів має опиратися на теоретичні положення семіотики мистецтва. Будь-який акт чи артефакт мистецтва, згідно 3 головним положенням даної концепції, інтерпретується як текст, тобто як знакова структура, що має свою усталену семантику i закономірну організацію. Часто дане уявлення втілюється дослідниками i педагогами в категоріях лексики і граматики мистецтва. Таким чином, шлях до об'єктивно обгрунтованої, позбавленої суб'єктивного свавілля педагогічної герменевтики творів традиційного мистецтва (за дослідженнями Л. Степанової та С. Шипа) відкриває ознайомлення майбутніх учителів музики і хореографії з національними художніми мовами різних народів, тобто - 3 тезаурусами художніх знаків і закономірностей їх системного використання в художньо-мовленнєвому процесі.

Одним 3 провідних принципів застосування герменевтичного підходу в мистецькій педагогіці $\epsilon$ формування у студентів психологічної установки сприйняття i навичок 
осмислення семантики окремих художніх знаків та цілісних формоутворень в контекстових «зрізах» різного рівня: від контексту просторово-часової структури одиничного артефакту національної традиції до найширшого контексту всієї художньої культури людства. Теоретичним орієнтиром в цьому можуть слугувати ідея «герменевтичного кола» (за Г. Гадамером).

Педагогічними умовами застосування герменевтичного підходу при освоєнні національних мистецьких традицій $\epsilon$, наприклад, «створення освітньо-комунікативного середовища засобами інтерактивних технологій та організаційних форм»; «спонукання до художньо-дослідницьких дій»; «оптимізація процесу вербальної інтерпретації світової художньо-культурної спадщини» та ін. [9, с. 10-11].

Четвертий підхід, який визначає сутність і форми реалізації запропонованої методики, визначено як діяльнісний підxід. Він оснований на педагогічних ідеях Я. Коменського, А. Дістервега, М. Басова, Л. Виготського, П. Гальперіна, В. Давидова, А. Леонтьєва, С. Рубінштейна, Д. Ельконіна та ін. Даний підхід вимагає «...орієнтації впливу навчання на формування всіх сторін розумової, емоційної та поведінкової сфер особистості» [8, с. 92]. Ця вимога $\epsilon$ обов'язковою для естетичної освіти, зокрема для вирішення завдань оволодіння національними мистецькими традиціями. В першу чергу, майбутньому вчителю музики $\mathrm{i}$ хореографії потрібно накопичити в процесі діяльності багатий досвід синестетичного сприйняття; широкий тезаурус полімодальних образних уявлень; естетично цілісних і емоційно забарвлених емпіричних знань; спрямованих раціональних спостережень i узагальнень.

У запропонованій методиці діяльнісний підхід конкретизується у низці педагогічних принципів. Один з них О. Рудницька визначила як «принцип урізноманітнення форм і видів діяльності». Дослідниця зазначила можливість змінювати всі сторони педагогічного процесу заради розширення й збагачення сфери діяльності учнівської молоді, а саме: «форми навчальних занять (класні або аудиторні, позакласні, самостійні, індивідуальні, групові, колективні та ін.); засоби педагогічного впливу; зміст педагогічної взаємодії; завдання самостійної роботи; співвідношення теоретичного і практичного навчального матеріалу; логіку викладу інформації; чергування видів навчальної діяльності (запам'ятовування, занотовування, робота з текстом та ін.); розумові операції (абстрагування, конкретизації, синтезу, аналізу тощо); прийоми засвоєння знань (сприйняття, осмислення, закріплення, використання); способи оперування знаннями (переформулювання, розподіл на смислові блоки, виділення головного, упорядкування переліку ключових слів, підготовка тез, постановка запитань і пошук відповідей на них тощо)» [там же, с. 93].

Висунутий О. Рудницькою принцип «урізноманітнення форм i видів діяльності» $\epsilon$ однаково корисним як для занять у загальноосвітній школі, так і для процесу фахової підготовки педагогів мистецтва. Для студентів педагогічних вишів - майбутніх учителів музики і хореографії - особливо ефективним $\epsilon$, на наш погляд, звернення до педагогічних принципів розвивального навчання. Зокрема, йдеться про принципи: навчання на доступно високому рівні труднощів; дотримання доступно високого темпу освоєння матеріалу; рефлексії і самооцінки отриманих студентом знань і умінь; проблемного викладення матеріалу; колективного рішення проблем (Brainstorming).

Приймаючи до уваги специфіку художнього сприйняття i навчальної мистецької діяльності, належна увага має бути приділена принципу індивідуально-диференційованого навчання, який втілюється у встановленні персональних завдань, стимулюванні особистісної діяльності, використанні засобів персонального моніторингу навчального процесу тощо.

Значні перспективи досягнення майбутніми вчителями музики і хореографії вищого рівня володіння національними мистецькими традиціями відкривається при впровадженні у практичну роботу методів інтерактивної педагогіки та педагогіки співпраці, а саме: рольових ігор, дискусій, командних інтелектуальних змагань, розробки колективних проектів. Чудові можливості для цього надає самий матеріал - обряди, міфи, казки, мотиви образотворчого 
мистецтва, сюжетні танки, пісні та інструментальні музичні твори, які містять величезний потенціал для застосування інтерактивних методів освіти.

\section{Висновки і перспективи подальшого дослідження проблеми.}

Важливою місією сучасної масової мистецької освіти є всіляке сприяння збереженню і розвитку традицій рідного національного мистецтва, формування у молодих людей художньої чутливості до мистецтва інших народів світу, виховання молоді в дусі толерантності і поваги до культурних цінностей людства. Сучасні вчителі музики i хореографії мають бути готовими до виконання даної цивілізаційної місії. 3 цього слідує необхідність забезпечення у педагогічних вишах ефективного процесу освоєння майбутніми вчителями мистецтва якнайширшого обрію національних мистецьких традицій.

Цьому завданню має слугувати методика, що опирається на органічно притаманні матеріалу і природні для поставленої педагогічної мети полікультурний, художньоінтегративний (поліхудожній), герменевтичний і діяльнісний підходи. В основу методики покладено педагогічні принципи діалогу культур, семіотичного осмислення художніх творів, контекстового аналізу семантики художніх знаків, урізноманітнення форм і видів навчальної діяльності; розвивального навчання. Практична реалізація зазначених підходів і принципів передбачає звернення до методів культурологічного осмислення традиційних артефактів мистецтва, компаративного аналізу, жанрового моделювання художньої культури, інтерактивного навчання, педагогіки співпраці.

Надана в статті загальна характеристика методики потребує подальшої розробки, зокрема конкретизації форм освітнього процесу, описання методичних прийомів, виявлення педагогічних умов оптимального застосування методики, встановлення критеріїв вибору артефактів, що репрезентують конкретні національні мистецькі традиції, наведення прикладів герменевтичного описання художніх текстів тощо.

\section{Література} $424 \mathrm{c}$.

1. Бахтин, М. М. Эстетика словесного творчества Текст.: монография. М.: Искусство, 1979. -

2. Бузова, Олена Дмитрівна. Поліхудожнє виховання як засіб удосконалення музичної підготовки майбутніх вчителів музики : автореф. дис. ... канд. пед. наук : 13.00.02; Нац пед. ун-т ім. М. П. Драгоманова. Київ, 2004. 19 с.

3. Вайнштейн. С. И. Сравнительно-исторический метод / Культурология. XX век. Энциклопедия. СПб.: Университетская книга; ООО Алетейя, 1998. С. 223-224.

4. Гадамер Ханс-Георг. Истина и метод. Перевод с немецкого Общая редакция и вступительная статья доктора философских наук Б. Н. Бессонова. Москва,"Прогресс", 1988. - 637 с.

5. Енциклопедія освіти / Акад пед. наук України, головний ред. В. Г. Кремень. К.: Юрінком Інтер, 2008. $1040 \mathrm{c.}$

6. Кобзев А.И. Духовная культура Китая: энциклопедия: в 5 т. / Гл. ред. М.Л.Титаренко; Ин-т Дальнего Востока. - Музика.: Вост. лит., 2006. Т. 1. Философия. 727 с.

7. Новая философская энциклопедия: В 4 т. Музика: Мысль. Под ред.. В. С. Степина. Том 4. 2001. C. 87-88.

8. Рудницька О.П. Педагогіка: загальна та мистецька: Навчальний посібник. Тернопіль: Навчальна книга. Богдан, 2005. 360 с.

9. Степанова, Л. В. Методика формування художньо-герменевтичної компетентності магістрів музичного мистецтва та хореографії [Текст] : автореф. дис. ... канд. пед. наук : спец. 13.00.02 - теорія та методика музичного навчання / Сумський державний педагогічний ун-т ім. А. С. Макаренка. Суми: СумДПУ ім. А. С. Макаренка, 2018. 20 с.

10. Философия: Энциклопедический словарь. / Под ред. А.А. Ивина. М.: Гардарики, 2004. 1072 с.

11. Цзинь Ли. Культурные основы обучения. Восток и Запад. Пер. с англ. А.Аполлонова, Т. Котельниковой. М.: Изд-во Высшей школы экономики, 2015.

12. Цзинь Синь Синь. Традиционная культура и ее роль в развитии образования Китая. https://cyberleninka.ru/article/n/traditsionnaya-kultura-i-ee-rol-v-razvitii-obrazovaniya-kitaya

13. Шип С. Иконические жанровые модели музыкальной культуры. Київське музикознавство. Вип. 13: Культурологія та мистецтвознавство. К., 2004. С. 3-13. 
14. Щолокова О.П. Методика викладання світової художньої культури. Підручник для студентів педагогічних університетів. Київ: Вид-во НПУ імені М.П.Драгоманова, 2013. 283 с.

\section{Про автора:}

Чжан Юй, аспірантка кафедри музичного мистецтва і хореографії (факультет музичної та хореографічної освіти), Південноукраїнський національний педагогічний університет імені К. Д. Ушинського (65020 Одеса, Україна), ORCID: 0000-0003-2993-9225

\section{Fundamentals of mastering national artistic traditions by the future teachers of music and choreography}

Zhan Yu

Relevance of the study is due, first of all, to the contradiction between the objective need of society for the preservation and development of national artistic traditions, on the one hand, and the low efficiency of the corresponding methods of mastering the aesthetic consciousness of students, on the other hand.

Literature Review. The author relies on classical works devoted to the development of cultural tradition in music and choreographic education (B. Bartok, E. Balchitis, E. Bashich, K. Vasilenko, V. Verkhovinets, V. Dzhulyanu, V. Kovalyv, Z. Koday, M Lysenko, F. Lisek, K. Orff, B. Trichkov). The experience of using national artistic traditions in the practice of training teachers of music and choreography at pedagogical universities is taken into account (D. Sharikov, L. Androshchuk, A. Maksimenko, G. Nikola, T. Razumenko, O. Tarantseva, O. Chepalov).

The purpose of this article is to determine pedagogical approaches, principles and methods of mastering national artistic traditions by future teachers of music and choreography

Methodology. The methods of categorical analysis of the concept of "tradition", of generalization and classification of specific approaches and principles of teaching are used. The method of explication of the concepts and provisions of philosophy, cultural studies, general art criticism, semiotics, hermeneutics in the field of training methodology for music teachers and choreography have been implemented.

Results. An important mission of modern mass art education is to contribute fully to the preservation and development of the traditions of native national art, the formation of young people artistic sensitivity to the art of other peoples of the world, educating young people in the spirit of tolerance and respect for the cultural values of humanity. Modern teachers of music and choreography should be ready to fulfill this civilization mission. This implies the need to ensure that pedagogical universities have an effective process of mastering by future teachers of art a wide range of national artistic traditions.

This task should be served by a technique based on organically inherent in the material itself and approaches that are natural for the set pedagogical purpose. These include: multicultural, artistic and integrative (polyartistic), hermeneutic and activity approaches. The methodology is based on the pedagogical principles of the dialogue of cultures, semiotic understanding of works of art as separate artistic signs and integral texts, contextual analysis of the semantics of works, a variety of forms and types of educational activity; developmental education concept. The practical implementation of these approaches and principles involves an appeal to the methods of culturological comprehension of traditional artifacts of art, comparative analysis, genre modeling of art culture, interactive learning, methods of pedagogy of cooperation.

The general characteristic of the methodology provided in the article requires further development, in particular, concretization of the forms of the educational process, a description of methodological techniques, identification of pedagogical conditions for the optimal application of the methodology, establishment of selection criteria for artifacts representing specific national artistic traditions.

Keywords: higher education methodology; education; national art tradition; pedagogical approach; choreographic education.

\section{References}

1. Bakhtin, M. (1979) Aesthetics of verbal creativity. Art, Moscow. [in Russian]

2. Buzova, O. (2004) Polikhudozhne vikhovannya yak zib udoskonalennya musically prepared music maybutnih readers of music: abstract dis. Kyiv. [in Ukrainian]

3. Weinstein. S. (1998). Comparative-historical method. Culturology. XX century. University book. Aletheia. SPb. [in Russian]

4. Gadamer Hans-Georg (1988). Truth and method. Translation from German. General edition and introductory article by B. N. Bessonov. Progress. Moscow. [in Russian] 
5. Encyclopedia of Education (2008). Acad. sciences of Ukraine, head ed. V. G. Flint. Yurinkom Inter. Kyiv. [in Ukrainian]

6. Kobzev A. (2006). The spiritual culture of China. In 5 volumes. East literature. Moscow. T. 1. Philosophy. P. 66-81. [in Russian]

7. New philosophical encyclopedia (2001). In 4 vols. Edited by V.S. Stepin. Volume 4. Thought. Moscow. - S. 87-88. [in Russian]

8. Rudnitska O. (2005). Universal pedagogy and Pedagogy of Art. Bogdan. Ternopil. [in Ukrainian]

9. Stepanova, L. (2018) Methodology of formulating artistic-hermeneutic competence of masters of the musical mystery and choreography. Abstract dis. Sumi. [in Ukrainian]

10. Philosophy: Encyclopedic Dictionary. (2004) Ed. A. Ivin. Gardariki. Moscow. [in Russian]

11. Jin Li. Cultural Foundations of Learning. East and West. (2015) Transl. from English A. Apollonova, T. Kotelnikova. Publishing House of the Higher School of Economics. Moscow. [in Russian]

12. Jin Xin Xin. Traditional culture and its role in the development of China's education. https://cyberleninka.ru/article/n/traditsionnaya-kultura-i-ee-rol-v-razvitii-obrazovaniya-kitaya [in Russian]

13. Shyp S. (2004) Iconic genre models of musical culture. Kyiv Musical Studies. Vol. 13. Kyiv. [in Russian]

14. Shcholokova O. (2013) Methodics of the World Art Culture. NPU in name of M.P. Dragomanov. Kyiv. [in Ukrainian]

About the author:

Zhan Yu, postgraduate student at the Department of Music Art and Choreography, Faculty of Music and Choreography, K. D. Ushynsky South Ukrainian National Pedagogical University (65020 Odesa, Ukraine);

ORCID: 0000-0003-2993-9225 